\title{
転がり軸受と部品の寿 命*
}

高、田浩 年**

Key words: rolling bearing, fatigue life, wear life, lubricant life, life distribution, component life, reliability physics, preventive maintenance.

\section{1. 緒言}

軸受は回転エネルギーを小さい損失で伀達し，精密な 回転渾動を案内する機械要素として，ほとんぞすべての 回転に不可欠のものである. 近年設備がシステム化, 巨 大化するにつれて使われる軸受の数も增大し，1個の軸

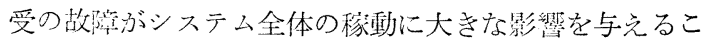
ともまれではなくなっている．軸受の保頼性，保全性へ の要求は高まる一方である.

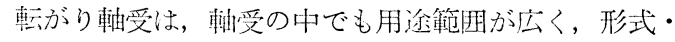
寸法が標準化されて互换性に富又，専阿メ一カの高度な 製造技術によって星産され，高精度な割注安価で入手 できる。しかも個々の用途汇応じた設計・利用技術があ るので，㢌切な選定・保守によってこそその機能を十分 に引き出すことができる，そ机には転がり軸受の信頼性 に対する理解が必要であり，その基礎的な事柄について 以下に䉮単滛触孔てみたい。

\section{2. 転がり軸受の寿命}

転がり軸受（以下軸受と記す）の寿命は広義には軸受 機能の持続性と解释され, 転がり疲れ (剥離), 磨耗大, クラック, 腐食, 過熱, トルク增大, 異音, 音・振動増 大, 精度劣化, 電食等々多くの形態がある. しかしこれ らの多くは, 軸受の選定, 使用法, 保守, 軸受预よび軸 受周辺の設計の不適切からくる初期故障ないし偶発故障 に相当するもので，避けるべき性質のものである，その 中に市って, 䟝離は転がり接触に伴う繰返し応力による 材料の疲労現象で, 程度の差はあっても避け難いの で，これを(狭義の) 寿命として扱らのが通例であ る. ISO等112)でもそのように定義されている. 以 下渌離寿命を主として考光る。な打磨耗技よび潤 滑戍劣化による寿命もある意味で不可避であり, そ れぞれ磨耗寿命, 㵎滑寿命として位置づけられる (後述参照).

剥離寿命（以下混同しない限り寿命之記す）は, そのばらつきの大きい点に特徵があり,これは剥離 機構と関係がある. 軸受寿命に関与する因子は極め

* 原稿受付 昭和 56 年 10 月 6 日.

** 正会員 日本精工(株)（藤沢市鹄沼神明 1-5-50)

1982 年 1 月
て多い（表 1）ら光，相互に関連している．各因子との 関係も近年解明が進んできているが，な拈不明な点もあ り，寿命が非可逆的現象であることも解明を難しくして いる. 現在, 軸受寿命計算式は

$$
L_{n a}=a_{1} a_{2} a_{3}(C / P)^{p}
$$

$\left(L_{n a}:(100-n) \%\right.$ 信頼度寿命, $10^{6}$ 回転, $C$ : 軸受基本 動定格荷重, $P$ : 等洒荷重, $p=3$ (玉軸受), $p=10 / 3$ (こ 万軸受), $a_{1}$ ：信頼度係数， $a_{2}$ ：材料係数， $a_{3}$ ：使用条件 係数)の簡単なものであるが， $a_{3}$ をはじめとする係数の より詳細な決定が今後の課題である.

\section{3. 軸受寿命の故障物理}

剥離の機構として以前から認められているものに，動 的最大せん断応力理論3 3 ) がある。これは，転がり接触 に伴い表面下 $z_{0}$ で転走面に平行な平面内に発生する動 的な最大せん断応力 $\tau_{0}$ が, 材料中のミクロな強度の弱 い部分に作用してクラックを生じ, 表面に到達して豩離 に至るとするものである，すなわち，材料中の微小体 積 $\Delta V$ の部分が応力 $\tau$ の $n$ 回の繰返し後に耐兄る確率を $\Delta S(n)$ ，そのときの材料の状態を久 $(n)$ とするとき，次 の $\mathrm{d} n$ 回の応力繰返しの間に状態の変化 $\mathrm{d} \lambda(n)$ を生じて クラックを生じる確率は, $\mathrm{F}\{\lambda(n)\} \mathrm{d} \lambda(n) \Delta V$ (F: 関数 記号) で示されるので, $n+\mathrm{d} n$ 回の応力繰返しに耐觉る 確率 $\Delta S(n+\mathrm{d} n)$ は, $\Delta S(n)$ と $[1-\mathrm{F}\{\lambda(n)\} \mathrm{d} \lambda(n) \Delta V]$ と の積になる.この関係を $\mathrm{d} n \rightarrow 0$ の極限値で表し，

$$
\frac{1}{\Delta S(n)} \frac{\mathrm{d} \Delta S(n)}{\mathrm{d} n}=-\mathrm{F}\{\lambda(n)\} \frac{\mathrm{d} \lambda(n)}{\mathrm{d} n} \Delta V
$$

\begin{tabular}{|c|c|c|}
\hline 分 & 類 & 内 \\
\hline $\begin{array}{l}\text { 軸 } \\
\text { 受 } \\
\text { 固 } \\
\text { 有 }\end{array}$ & $\begin{array}{l}\text { 軸受設計 } \\
\text { 軸受精度 } \\
\text { 軸受材料 } \\
\text { 軸受製造 }\end{array}$ & $\begin{array}{l}\text { 軸受内部寸法諸元, 軸受形式等 } \\
\text { 面粗さ, 形状・寸法誤差, 回転精度, すきま等 } \\
\text { 材質, 製鋼法, 非金属介在物, 地きず, 鍛造比等 } \\
\text { 素材加工, 熱処理, 仕上加工条件等 }\end{array}$ \\
\hline $\begin{array}{l}\text { 使 } \\
\text { 用 } \\
\text { 条 } \\
\text { 件 }\end{array}$ & $\begin{array}{l}\text { 取付け } \\
\text { 荷 重 } \\
\text { 回 転 } \\
\text { 潤 滑 } \\
\text { 雾囲気 }\end{array}$ & $\begin{array}{l}\text { はめあい, 軸受配置, 支持材料, 支持剛性等 } \\
\text { 大きさ, 方向, 時間的変動, 衝撃の程度等 } \\
\text { 速度, 変動, 回転輸の種類, 停止 ·運転サイクル等 } \\
\text { 潤滑剤 (種類, 粘度, 添加剤), 給油量, 温度, 方 } \\
\text { 法, 異物等 } \\
\text { 雾囲気ガス, 異物・水分, 温度, 湿度, 圧力等 }\end{array}$ \\
\hline
\end{tabular}

表 1 剝離寿命に関係する因子 
これを $n=0$ から $N$ まで積分し, 右辺の積分を $\mathrm{G}\{\lambda(N)\}$ で表す. 全体積 $V$ が応力 $\tau$ の $N$ 回の繰返し後付耐える 確率 $S(N)$ は, 個々の $\Delta V$ が耐える確率の積と考兄られ るので

$$
\log _{S(N)} \frac{1}{V}=\int_{V} \mathrm{G}\{\lambda(N)\} \mathrm{d} V
$$

を得る。また， $\lambda(N)$ の $N$ に上る変化は応力 $\tau(N)$, 深 さ $z$ 抢よび $\lambda(N)$ 自体の関数と考学ら机, 次式で示され る.

$$
\frac{\mathrm{d} \lambda(N)}{\mathrm{d} N}=\mathrm{J}\{\lambda(N), \tau(N), z\}
$$

ここで関数 $\mathrm{G}, \mathrm{J}$ を $\lambda(N)$ の指数関数

$$
\begin{aligned}
& \mathrm{G}\{\lambda(N)\}=\kappa\{\lambda(N)\}^{g} \\
& \mathrm{~J}\{\lambda(N), \tau(N), z\}=\{\lambda(N)\}^{1-g / e} \mathrm{~K}\{\tau(N), z\}
\end{aligned}
$$

(K: 関数記号) で与学ると, 次式を得る.

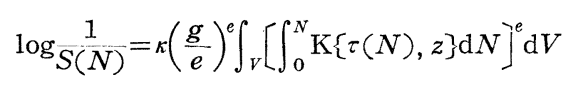

$\tau(N)=\tau_{0}, \quad z=z_{0}$ と考光, 各々 $\log 1 / \mathrm{S}(N)$ 飞対して指 数関数（指数： $c,-h)$ を仮定し, $a, l$ を接触半幅々接触 長さとするとき, 次の関係が得られる.

$$
\log _{S(N)} \propto N^{e} \tau_{0}{ }^{c} z_{0}{ }^{-h}\left(a z_{0} l\right)
$$

式 (5)を軸受諸元と材料に関する定数で表して軸受の $C$ と寿命計算式とを導くものである.この理論は, 現在も 軸受寿命計算式の基盤となっている.

以上の理論は軸受内部の最大応力付近の欠宿に注目し た内部起点説であり, 実駼結果ともある程度対応してい る. しかし欠陥の大きさ, 接線力, 潤滑の影蠁には触れ ていない，その後の研究によって，軸受表面の欠陥（介 在物, 巨大炭化物，小孔，条痕，圧痕等)，西るいは表 面粗さの凹凸の塑性変形と疲労による表面劣化を起点と する剝離も存在することが解明され，内部起点剝離と表 面起点剝離を総合した理論の体系化が試反られるように なった5) 8).すなわち, $\phi_{i}, \phi_{i}{ }^{\prime}$ を内部起点および表面起 点剥離のハザード因子とし， $f$ を接線力の影響を示す值 として, 次を導いた。

$$
\begin{aligned}
\log \frac{1}{S}= & N^{e}\left\{\phi_{0} \phi_{1} \phi_{2} \phi_{3} \phi_{4}+\phi_{0} f_{2 S}\right. \\
& \left.\times\left(\phi_{2 a^{\prime}}+\phi_{2 f^{\prime}}\right) f_{3 f} \phi_{3, \mu=0}^{\prime} \dot{\phi}_{4}{ }^{\prime}\right\}
\end{aligned}
$$

$\left(\phi_{0}, \phi_{1}, \phi_{0}{ }^{\prime}\right.$ : 材料汇関する值, $\phi_{2 a^{\prime}}{ }^{\prime}$ : 表面凹凸接触数, $\phi_{2 f^{\prime}}$ : 表面条痕・圧痕数, $\phi_{3, \mu=0}^{\prime}$ ：接線力のない場合の 応力の厳しさ因子, $\phi_{4}{ }^{\prime}$ : 幾何形状に関する值). 諸量を 適当に与えた計算結果は, 実駼結果(例兄ば図 19) ) に類 似した傾向を示している.これによって, 油膜厚さ・表 面粗さ比 $\Lambda$ の大き領域で内部起点剥離が， $\Lambda$ の小さい 領域で表面起点剥離が支配的となる様子が定量化され

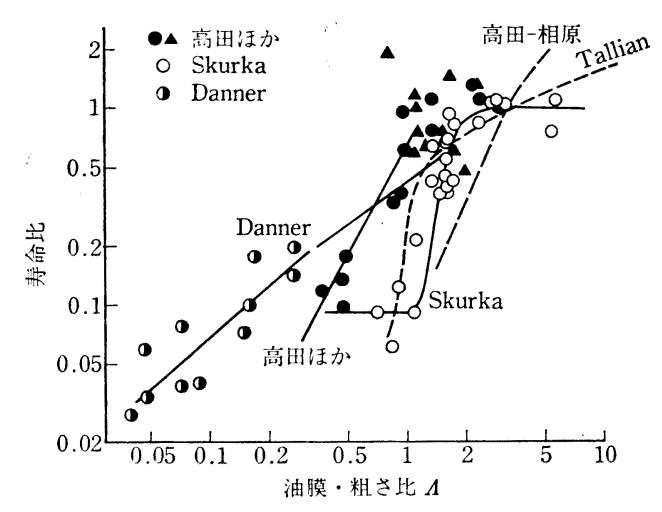

図 1.1 と寿命との関係

た。

\section{4. 寿命分布と最小寿命}

軸受寿命を渗める材料内部や表面のミクロな強度（ま たは欠陷) の分布は確涼的にランダム性が強いので, 寿 命のばらつきは大きい，この寿命值がワイブル分布

$$
\ln \ln 1 / S=e \ln L+\ln L_{0}
$$

（ $L_{0}$ ：軸受設計と使用条件で定省る値）に従うことは， 多くの軸受寿命試駼結果の示すところであり，式(5),(6) もこれを表している，その形状パラメータ $e$ は 1 より や大きい程度の值が多く, 理諭3)4)では実験による平均值

$$
\boldsymbol{e}=10 / 9 \text { (玉軸受) } 9 / 8 \text { (ころ蟿受) }
$$

を用いている。軸受寿命は通常 $90 \%$ 信頼度寿命 $L_{10}$ を 用いるので, 平均寿命はその数倍になる. 平均寿命基準 ではそれ以前淸命に至るものが多く，実用的でない， むしろより信頼度の高い寿命值を必要とする場合があ り,これを信頼度係数 $a_{1}$ で与兄る。

$a_{1}$ は実駼によって定まる $90 \%$ 以上の儲頼度での寿命 分布から， $a_{1}=L_{n} / L_{10}$ に上って求わられる. 主な実験 値10)〜14）をま之あると図2 劣得る12)13). ISO1)など規 格化された $a_{1}$ 值（表2）は，ワイブル形状パラメータを 1.5 とした值に相当している.

軸受の信赖度に対しては，高信刺度域での寿命之共に 最小寿命の論議が不可欠で方る。軸受の最小寿命はその 有無も含めて，母集団全体を如何に考光るかに上って異 なり得るし，最小寿命の物理的意味が必ずしも明りょう になってはいないが，実験的にはその存在を推定させる 結果が多い(図 2). Tallian10) は約 2500 個の軸受の寿命 值を基準化して総合し（図 3)，最小寿命を

$$
\left.\begin{array}{rl}
L_{\min }= & \left.0.053 L_{10} \text { (玉軸受 }\right) \\
& \left.0.055 L_{10} \text { (ころ軸受 }\right)
\end{array}\right\}
$$

と推定した。この注か軸受 500 個の結果污ら最小寿命を $0.05 L_{10}$ と推定した例11) もある. $L_{\min }$ は保全性の体系化 に資するためにも，今後の追究が望ま礼る。 


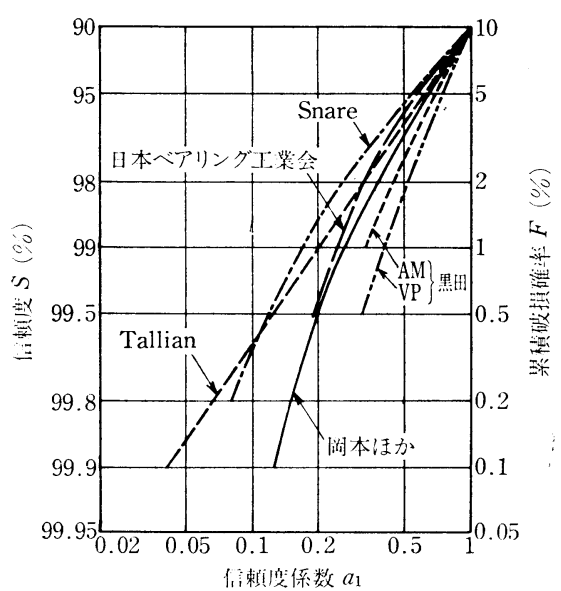

図 2 信頼度係数 $a_{1}$ の実験值

表 2 信頼度係数 $a_{1}$ の値 (ISO, BAS)

\begin{tabular}{c|c|c|c|c|c|c}
\hline$S(\%)$ & 90 & 95 & 96 & 97 & 98 & 99 \\
\hline$a_{1}$ & 1 & 0.62 & 0.53 & 0.44 & 0.33 & 0.21 \\
\hline
\end{tabular}

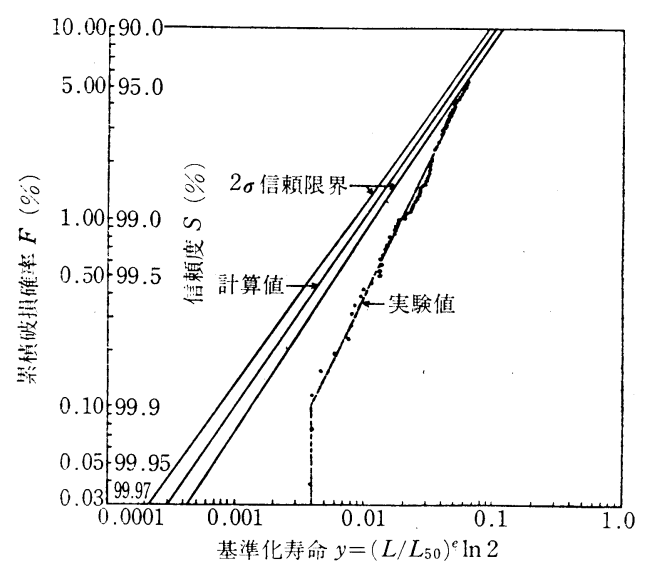

図 3 最小寿命の疤験による推定 (Tallian)

\section{5. 部品寿命と軸受寿命}

軸受は部品（内輪, 外輪, 転動体) のいずれかに 1 か 所で妇剝離を生ずると寿命に至るので，軸受寿命は部品 寿命の直列モデルである. 信頼度 $S$, 基本動定格荷重 $C$, 寿命 $L$ の, 内輪, 外輸, 転動体に関する值をそれぞれ 添字 1,2,3 で表すとき, 前記理諭3)4)では次になる.

$\ln 1 / S=\ln \left(1 / S_{1} S_{2}\right)$

$C=\left\{1+\left(C_{1} / C_{2}\right)^{p e}\right\}^{-1 / p e} \cdot C_{1}$

$L=\left(L_{1}^{-e}+L_{2}^{-e}\right)^{-1 / e}$

$C_{1}, C_{2}$ は軸受寸法諸元と材料で決まり, 計算可能である ので, 部品寿命 $L_{1}, L_{2}$ と軸受寿命 $L$ との関係が得られ る. この解析では $L_{3}$ は $L_{1}, L_{2}$ の内に分割して織り込

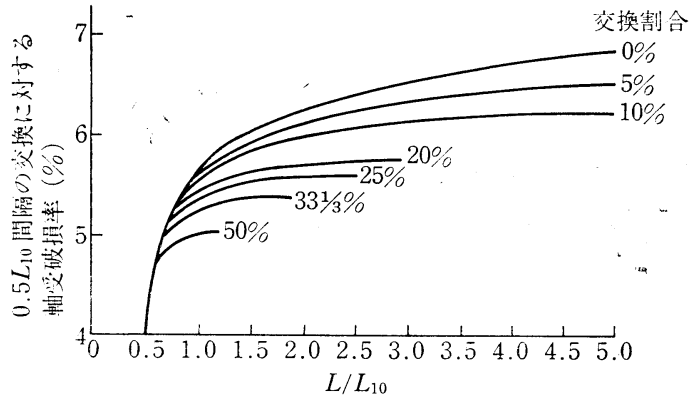

図 4 軸受の交換による信頼度の変化 (Harris ら)

まれ，明りょうには表れていない，高田15)は解析によっ て $C_{3}$ の式を直接与光,

$$
\begin{aligned}
& S=\prod_{j=1}^{3} S_{j} \\
& C=\left(\sum_{j=1}^{3} C_{j}-p e\right)^{-1 / p e} \\
& L=\left(\sum_{j=1}^{3} L_{j}-e\right)^{-1 / e}
\end{aligned}
$$

によって内輪, 外輪, 転動体各部品としての寿命と軸受 寿命との関係を示した. いずれも部品寿命の分布にワイ ブル分布を仮定しているが，これは軸受部品の寿命評価 などから妥当なものといえる、ただし，部品寿命と軸受 寿命との実験的対応には, 負荷分布, 応力体積等で単純 に比較できない面がある。

部品間の剝離強度の比較あるいは部品破損比率は, $C_{1}, C_{2}, C_{3}$ 間の大小関係に依存する。しふし，転がり接 触部の油膜形成や面粗さ等も関与することが最近解明さ れて㧍り9), 単新ではない。

\section{6. 軸受系の寿命と交換による信頼度}

1 台の装置やシステムには通常多数の軸受を用いるの で，その系沉長性がない限り，系全体の軸受の信頼度 $S$ は各軸受の信頼度 $S_{k}(k=1,2, \cdots, n)$ の積である．5章 と同様の考光から, 系全体の軸受の寿命 $L$ と個々の軸受 寿命 $L_{k}$ との間に次の関係が成り立つ.

$$
L=\left(\sum_{k=1}^{n} L_{k}^{-e}\right)^{-1 / e}
$$

これは, システムの軸受系としての設計信頼度に対応 する. 現実には軸受が寿命に至れば交換するし, 予防保 全の立場から軸受を寿命前に交換することもある. これ らの場合, 軸受系としては再生過程に入るので信頼度が 変化する. Harris ら16) は, 系の各軸受が最小寿命をも つ場合も含めて等しいワイブル分布(計算寿命も等しい) をなすとして，ある定期交換周期で任意の割合の軸受を 交換した場合の軸受系の信頼度を, 再生関数と近似式を, 用いて計算した。図 4 は結果の一例であり, 交換軸受数 


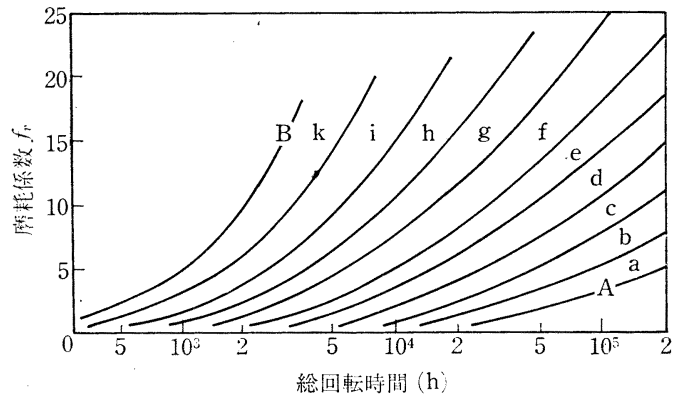

図 5 磨耗寿命の推定曲線 (Eschmann ら)

の増大に伴う信頼度の向上がみられる.

\section{7. 磨耗寿命と潤滑寿命}

既述の剥離寿命之同様不可避的なものとして，軸受の 磨耗および潤滑剤劣化による寿命がある.

軸受内の接触部分を常に完全に油膜で分離することは 不可能に近いので，磨耗が発生し磨耗寿命が存在する。 磨耗は接触状態, 運動, 構造, 潤滑等に依存するう光, 磨耗寿命の基準が軸受用途に応じて異なるので，磨耗寿 命の一般式は作り難い. 試行的な例として，磨耗係数 $f_{v}$ を軸受すきま増加量 $V$ と軸受寸法から定まる係数 $e_{0}$ とで

$$
f_{v}=V / e_{0}
$$

で表し, $f_{v}$ の運転時間に伴ら変化をいくつかの領域に分 類して与え (図 5), 軸受の用途と概略の $f_{v}$, 磨耗領域之 を別に対応づけて磨耗寿命を推定する方法17)がある。磨 耗寿命の信頼度を論じた例はみられない。

潤滑寿命は，潤滑剂がその機能を失い軸受の正常運転 が不可能となるに至る期間である，潤滑剤の機能低下は 点検による各種性状值 (粘度, 酸価, 含有不純物, 滴点, らょら度等) の変化から判定でき, 寿命の代用特性が存 在する点に剥離寿命との相違がある。しかし，点検の不 可能なグリース封入軸受では, 潤滑寿命の推定が必要に なる.グリース潤滑寿命 $L_{g}$ には多くの実験式があるが, おおされね軸受温度 $T$ の関数, 例えば $k_{1}, k_{2}$ を定数として

$$
\log L_{g}=k_{1}-k_{2} T
$$

で与えられている18)19). $L_{g}$ もワイブル分布で整理でき, 形状パラメータは大きく，4程度の実験例18)もある。な お式(18)の $L_{g}$ は平均寿命を表す。この他にグリースの交 換給脂の周期を速度と軸受径から見積もる図表もある.

\section{8. 結 言}

転がり軸受の剝離寿命を中心に，信頼性と保全性に関 係する事柄の解説を試みた，その保全性の向上には，軸 受自体のメンテナンスフリー化と, 寿命・故障の予知が 極めて有効である，前者の例として，圧延機ロールネッ
ク軸受や鉄道車両ジャーナル軸受のグリース密封化と異 物・水の侵入防止策による, 寿命と保全周期の大幅な延 長が報告20)されている. また後者の例としては, 運転中 の軸受振動の計測・解析による軸受の剥離, 面荒れ, 焼 付きの早期検知 21$)$, 潤滑油中の微小磨耗粉の観察によ る軸受の剝離等の検出が報告されており，共に装置の実 用化が図られている。

転がり軸受は構造が単純な割には寿命の挙動が複雑で あり，信赖性の考光も古くから定着している，その保全 性・信頼性を更に向上させるために，今後も地道な研究 の積上げが期待される.

\section{文献}

1) ISO R 281: Rolling Bearings, Methods of Evaluating Dynamic Load Ratings.

2）JIS B 1518: 転がり軸受の動定格荷重の算方法。

3) G. Lundberg \& A. Palmgren: Dynamic Capacity of Rolling Bearings, IVA Handlingar, 196, (1947) 1.

4) G. Lundberg \& A. Palmgren: Dynamic Capacity of Roller Bearings, IVA Handlingar, 210, (1952) 1.

5) Y.P.Chiu, T.E. Tallian \& J.I. McCool: An Engineering Model of Spalling Fatigue Failure in Rolling Contact (I), Wear, 17, 5/6, (1971) 433.

6) T.E. Tallian \& J. I. McCool: ibid, (II). Wear, 17, 5 / 6, (1971) 447.

7) T.E. Tallian: ibid. (III), Wear, 17, 5/6, (1971) 463.

8) J. Y. Liu, T.E. Tallian \& J. I. McCool: Dependence of Bearing Fatigue Life on Film Thickness to Surface Roughness Ratio, ASLE Trans., 18, 2, (1975) 144.

9）高田浩年，鈴木 進，前田悦生：ころ軸受の疲れ寿命に

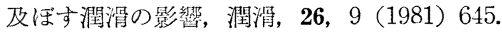

10) T. Tallian: Weibull Distribution of Rolling Contact Fatigue Life and Deviations Therefrom, ASLE Trans., 5, 1, (1962) 183.

11) B. Snare: How Reliable are Bearings, The Ball Bearing J., 162, (1970) 3.

12）日本ベアリング工業会寿命試験分科会：ころがり軸受寿 命におよほす材料の影響に関する試験, 日本機械学会誌, 76, 660 (1973) 1368

13）网本純三ほか：ころがり軸受の最短寿命に関する棒駼的 研究, 潤滑, 22, 5 (1977) 307.

14）黑田昌夫：ころがり軸受の定格荷重と寿命，潤滑， $\mathbf{1 7}, 9$ (1972) 569.

15）転がり軸受工学編集委員会：転がり 軸受工学，盖筫堂 (1975) 188.

16) T. A. Harris, S. F. Aaronson \& R. Piante: The Effect of Partial Replacement on the Reliability of a Closed Group of Rolling Bearings, Lub. Engg., 22, 8,(1966) 310.

17) P.Eschmann et al. : Das Leistungsvermögen der Wälzlager, Springer, Berlin, Göttingen u. Heidelberg, (1964) 90.

18）鈴木利郎，鉿木富太：密封玉軸受のグリース寿命, NSK Bearing J., 629 (1971) 1.

19) R. L. Smith \& D. S. Wilson: Reliability of Greasepacked Ball Bearings for Fractional Horse-power Motors, Lub. Engg., 36, 7, (1980) 411.

20）馬場光一，大川文雄，鈴木三千男：メンテナンスを考え た軸受の応用設計，機械設計， 25，11（1981） 31.

21）五十嵐昭男, 野田万杂, 松息英一：転がり軸受の異常予 知に関する研究 (第 1 報), 潤滑, 24, 2 (1979) 122 